\title{
LYMPHOCYTE DNA AND RNA CONTENT IN RHEUMATOID ARTHRITIS
}

\author{
BY \\ A. C. A. GLEN* \\ Department of Biochemistry, Western Infirmary, Glasgow, \\ AND \\ M. K. JASANI $\dagger$ \\ Centre for Rheumatic Diseases, Glasgow
}

Rheumatoid factor and antinuclear factors present in the sera of a high proportion of patients with rheumatoid arthritis have many of the characteristics of autoantibodies (Glynn and Holborow, 1965). These serum autoantibodies do not appear to be primary in the pathogenesis of the disease (Harris and Vaughan, 1961) although rheumatoid factor may sustain joint inflammation (Restifo, Lussier, Rawson, Rockey, and Hollander, 1965). It is possible that cell-bound immunity or delayed hyper-. sensitivity may be the important mechanism in the disease process (Doniach and Roitt, 1962) which would implicate sensitized lymphocytes as the effectors of tissue damage (Holborow, 1967). We have therefore studied the lymphocytes of peripheral blood in rheumatoid patients. The DNA and RNA content of suspensions of isolated cells was measured; the DNA to establish cell numbers, and RNA content as an index of their protein synthetic activity.

\section{Material and Methods}

\section{Patients}

A total of 35 patients with rheumatoid arthritis was studied. Of these 24 had definite rheumatoid arthritis by the American Rheumatism Association criteria (Ropes, 1959); 21 of this group were female, and their mean age was 55 years (range 25 to 78). The remaining eleven patients had probable rheumatoid arthritis; ten were female, and their mean age was 47 years (range 25 to 70 ). Forty healthy individuals, mostly hospital staff, served as controls; twenty controls were female, and their mean age was 35 years (range 18 to 77 ).

\section{Estimation of DNA and RNA}

The method for analysis of the DNA and RNA content of peripheral blood lymphocytes has been described elsewhere (Glen, 1967). It was carried out in two stages.

(1) To separate the lymphocytes from the other

Present Appointments:

* Senior Registrar, Department of Biochemistry, Victoria Infirmary, Glasgow:

tC.I.B.A., Clinical Research Fellow. blood cells, $20 \mathrm{ml}$. venous blood were withdrawn frone each patient and the lymphocytes separated by a modifi cation of the method of Coulson and Chalmers (1964) which utilizes a gelatin solution to accelerate cell sedi $-\mathrm{V}$ mentation. Red cells were removed by osmotic shockî and the lymphocytes were obtained with less than 10 per cent. contamination with other cells, usually polymor phonuclear leucocytes; a smear from each sample being checked for purity before analysis.

(2) Measured numbers of cells, always greater than $3 \times 10^{6}$ were then submitted to a modified Schmidț Thannhauser separation (Fleck and Munro, 1962), and the separated DNA and RNA fractions of the lymphoso cytes analysed by ultraviolet absorbtiometry. Thẹ results obtained gave the DNA and RNA content of het peripheral blood lymphocytes in each patient expres as micrograms $(\mu \mathrm{g}$.) DNA phosphorus (DNAP) RNA phosphorus (RNAP) per million cells.

A previous report (Glen, 1967) showed that the aboveू analytical method was reproducible within \pm 5 per cent? When the error introduced by cell counting was $\vec{B}$ eliminated by expressing the results as the ratio of RNAP/DNAP, the mean variation in duplicate was reduced to \pm 3.8 per cent.

DNA

\section{Results}

The results are summarized in Fig. 1 and Tables I and II (opposite).

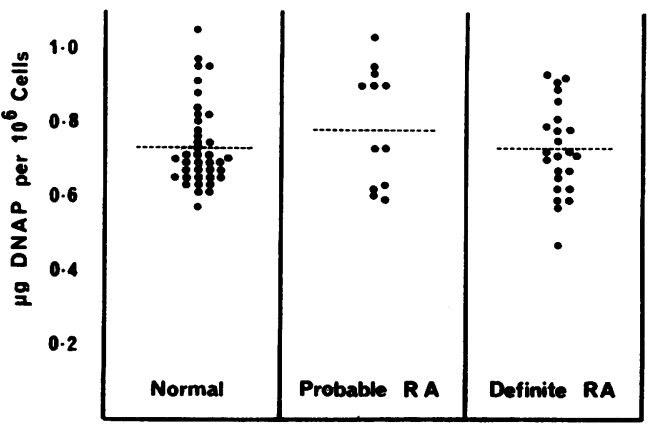

Fig. 1.-DNA content of blood lymphocytes in normal individua and patients with probable and definite rheumatoid arthritis. 
TABLE I

MEAN DNAP AND RNAP

\begin{tabular}{|c|c|c|c|c|}
\hline Group & $\begin{array}{l}\text { Number } \\
\text { of } \\
\text { Individuals }\end{array}$ & $\begin{array}{c}\text { Mean DNAP } \\
\text { ( } \mu \text { g. per } 10^{\circ} \text { Cells) } \\
\pm \text { S.D. }\end{array}$ & $\begin{array}{l}\text { Mean RNAP } \\
\text { ( } \mu \mathrm{g} . \text { per } 10^{\circ} \text { Cells) } \\
\pm \text { S.D. }\end{array}$ & $\begin{array}{l}\text { Ratio } \\
\text { RNAP/DNAP } \\
\pm \text { S.D. }\end{array}$ \\
\hline $\begin{array}{l}\text { Normal } \\
\text { Probable Rheumatoid Arthritis } \\
\text { Definite Rheumatoid Arthritis }\end{array}$ & $\begin{array}{l}40 \\
11 \\
24\end{array}$ & $\begin{array}{l}0.73 \pm 0 \cdot 12 \\
0.76 \pm 0.16 \\
0.73 \pm 0.12\end{array}$ & $\begin{array}{l}0.19 \pm 0.06 \\
0.23 \pm 0.07 \\
0.27 \pm 0.07\end{array}$ & $\begin{array}{l}0 \cdot 26 \pm 0.06 \\
0 \cdot 30 \pm 0.05 \\
0 \cdot 37 \pm 0.05\end{array}$ \\
\hline
\end{tabular}

TABLE II

\begin{tabular}{|c|c|c|c|c|c|}
\hline \multirow{2}{*}{ Measure } & \multirow{2}{*}{ Analysis } & \multicolumn{2}{|c|}{ Degrees of Freedom } & \multirow{2}{*}{$\mathbf{F}$} & \multirow{2}{*}{$\mathbf{P}$} \\
\hline & & $v_{1}$ & $v_{2}$ & & \\
\hline RNAP & $\begin{array}{l}\text { Normal v. Definite + Probable RA } \\
\text { Normal v. Definite RA } \\
\text { Normal v. Probable RA } \\
\text { Probable v. Definite RA }\end{array}$ & $\begin{array}{l}1 \\
1 \\
1 \\
1\end{array}$ & $\begin{array}{l}73 \\
62 \\
49 \\
33\end{array}$ & $\begin{array}{r}17 \cdot 5 \\
24 \cdot 7 \\
2 \cdot 5 \\
2 \cdot 9\end{array}$ & $\begin{array}{l}<0.001 \\
<0.001 \\
>0.05 \\
>0.05\end{array}$ \\
\hline RNAP/DNAP Ratio & $\begin{array}{l}\text { Normal v. Definite }+ \text { Probable RA } \\
\text { Normal v. Definite RA } \\
\text { Normal v. Probable RA } \\
\text { Probable } v \text {. Definite RA }\end{array}$ & $\begin{array}{l}1 \\
1 \\
1 \\
1\end{array}$ & $\begin{array}{l}73 \\
62 \\
49 \\
33\end{array}$ & $\begin{array}{c}31 \cdot 2 \\
43 \cdot 0 \\
2 \cdot 8 \\
11 \cdot 95\end{array}$ & $\begin{array}{l}<0.001 \\
<0.001 \\
>0.05 \\
<0.01\end{array}$ \\
\hline
\end{tabular}

No significant difference was found between the DNA phosphorus content of the circulating lymphocytes from patients with rheumatoid arthritis and normal individuals. The mean for the definite rheumatoid arthritis group was identical with that for the normal series, $0.73 \mu \mathrm{g}$. DNAP per $10^{6}$ cells; the lymphocytes from the probable rheumatoid group had a higher mean DNA phosphorus content, $0.76 \mu \mathrm{g}$. DNAP per $10^{6}$ cells, but this difference was not significant. No significant difference in the DNA phosphorus content of the lymphocytes was noted between males and females in either the rheumatoid patients or the control subjects.

\section{RNA}

The results are summarized in Fig. 2 and Tables I and II. The mean RNA phosphorus content of the circulating lymphocytes in definite rheumatoid arthritis, $0 \cdot 27 \mu \mathrm{g}$. RNAP per $10^{6}$ cells, was significantly different from the control group, 0.19 $\mu \mathrm{g}$. RNAP per $10^{6}$ cells $(P<0.001)$. The mean RNA phosphorus content of the lymphocytes of patients with probable rheumatoid arthritis was $0.23 \mu \mathrm{g}$. per $10^{6}$ cells, and analysis of variance of the results showed no significant difference from the control values.

\section{RNAP/DNAP Ratio}

This was calculated for each patient and control from the results of the RNAP and DNAP analyses. The RNAP/DNAP ratios of the lymphocytes in patients and controls are shown in Fig. 3 and summarized in Tables I and II. The means for the ratios in the three groups were: 0.30 for patients with probable rheumatoid arthritis, 0.37 for patients with definite rheumatoid arthritis, and 0.26 for normal subjects. The definite rheumatoid group

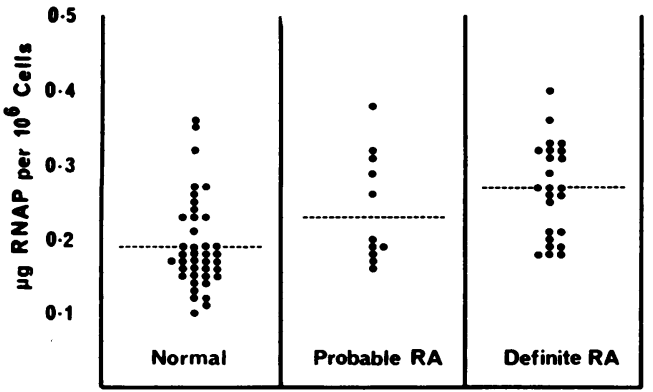

Fig. 2.-RNA content of blood lymphocytes in normal individuals and patients with probable and definite rheumatoid arthritis.

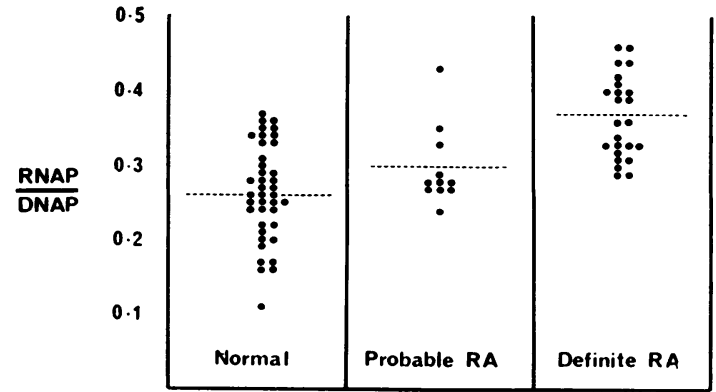

Fig. 3.-RNA/DNA ratio of blood lymphocytes in normal individuals and patients with probable and definite rheumatoid arthritis. 
was significantly different from the normal $(P<$ 0.001 ). The probable rheumatoid group was not significantly different from the normal, but differed significantly from the definite rheumatoid group $(\mathrm{P}<0.01)$.

It was possible to match for age and sex, ten patients with definite rheumatoid arthritis and ten controls. Pairings were carried out by random selection when more than one match was available. The lymphocyte RNAP/DNAP ratio was again different in the matched groups; the mean ratio for patients with definite rheumatoid arthritis was $0 \cdot 37 \pm 0.04$ and for normal subjects $0.26 \pm 0.03$ $\mathrm{P}<0.001$ ).

No close correlation was found between the RNAP/DNAP ratio of the lymphocytes and the clinical or laboratory features of rheumatoid arthritis, although, as shown above, clear differences were noted between the patients with probable and definite rheumatoid arthritis when considered as groups.

\section{Discussion}

The results of analyses of the DNA phosphorus (DNAP) content per $10^{6}$ cells of the blood lymphocytes in rheumatoid arthritis and in normal individuals are close to the expected diploid amount for man (Leslie, 1960). DNA phosphorus is thus a good index of cellularity, and hence the mean RNA of the lymphocytes may be expressed as the RNA phosphorus/DNA phosphorus (RNAP/DNAP) ratio of the cells.

The interpretation of the rise in the average RNA content of the blood lymphocytes in rheumatoid arthritis is complicated by the diversity of the blood lymphocyte both in origin and in morphology.

Blood lymphocytes are in part newly-formed cells derived from bone marrow or spleen (large and medium-sized cells) and part recirculating lymphocytes (small lymphocytes) which enter the tissues from the blood stream, percolate through to the lymphatics passing through lymph nodes, and reenter the blood stream by way of the major lymphatic trunks (Gowans, 1959). Some of these small lymphocytes are known to have a prolonged life span, recirculating from blood to lymph repeatedly over a number of years (Buckton, Jacobs, Court Brown, and Doll, 1962). The lymphocytes of the thoracic duct which comprise the bulk of the recirculating cells were studied in animals by Everett, Caffrey, and Rieke (1964), who observed that exposure of the animal to antigen produced an increase in the size and the protein synthetic rate of the small lymphocytes entering the circulation. These alterations must also imply an increase in the RNAP/DNAP ratio of the lymphocytes. Thus a rise in the mean RNA content of the periphera blood lymphocytes can occur in several ways. $\frac{.}{3}$ Firstly, by an increase in the numbers of circulating large lymphocytes (either absolute or relative), or secondly, by an increase in the RNA content of: the individual cells, either large lymphocytes, or thes? smaller lymphocytes, or both.

It is likely that increased immunologica $\frac{\text { 음 }}{-}$ activity will result in an increased production of newly-formed and hence large lymphocytes. Wardle $e^{\mathbb{\Phi}}$ and Attan (1967) observed hyperplasia of lymphoide elements in the bone marrow of patients with rheumatoid arthritis. Everett and others (1964), in their studies of the effect of antigens on the lympho- $\vec{\omega}$ cytes, observed an increase in the size of the long- $-\frac{}{\circ}$ lived lymphocytes and called the enlarged small lymphocytes "activated cells". It is possible that, i in rheumatoid arthritis, in the presence of increased immunological reaction, a proportion of the lymphocytes carry increased amounts of RNA and are akin to Everett's activated cells.

It is well established that small lymphocytesrespond in vitro to a series of agents, either specific, $\bar{Z}$ such as tuberculin purified protein derivative and pertussis vaccine, or non-specific, such as phyto-今 haemagglutinin (Hirschhorn, Bach, Kolodny, Fir- $\vec{\bullet}$ schein, and Hashem, 1963). This transformationo response is characterized by an increase in severalo features of the cell, including size, rates of nuclencic acid synthesis, and RNA content. A parallel hats been drawn between the behaviour of the cells in vivo and their response in vitro, and this is of speciall interest in rheumatoid arthritis. Lymphocytes will $\stackrel{\varrho}{\Rightarrow}$ transform in vitro when exposed to antisera to $\overrightarrow{\overrightarrow{0}}$ $\gamma$-globulin (Sell and Gell, 1965). A similar response in vivo to rheumatoid factor, circulating antibody to $\gamma$-globulin, could be an explanation for increased amounts of RNA in the circulating lymphocytes in $\frac{0}{2}$ rheumatoid arthritis.

The possibility that drug treatment of patients with rheumatoid arthritis has influenced the RNAP/O DNAP ratio of the lymphocytes in this series has been considered. All of the patients investigatedo were taking salicylates or steroids or both. High lymphocyte RNAP/DNAP ratios occurred in theo patients studied irrespective of these categories. It is known that the immediate effect of steroids is too reduce the number of small lymphocytes, however N the effect of prolonged therapy tends towards N recovery of the pre-treatment state (Glen, Cooper, $\omega$ Jacob, Boak, Murray, and Munro, 1967). In the present series there was no significant difference in the RNAP/DNAP ratios of those receiving steroids and the rest.

Although the precise cause of the change in the lymphocyte RNAP/DNAP ratio has not been 
defined, the data show that the ratio is frequently increased in the blood lymphocytes of patients with rheumatoid arthritis. How this observation may be linked to the pathogenesis of the disease remains an open question; however the demonstration by Birbeck and Hall (1967) of the transformation in vivo of large basophilic lymphocytes (released by a lymph node on antigenic stimulation) into plasma cells makes it very likely that lymphocytes are indeed the effectors of cell-bound immunity.

\section{Summary}

The average cell DNA and RNA was measured in lymphocytes obtained from the peripheral blood of 24 patients with definite and eleven with probable rheumatoid arthritis, according to the American Rheumatism Association diagnostic criteria. Similar measurements were made in forty healthy individuals. A significant increase in the RNA content of the lymphocytes in patients with definite rheumatoid arthritis when compared with the controls was demonstrated. Possible reasons for this difference are discussed in relation to the known reactions of the lymphocyte to immunological stimuli and to drug treatment. It is concluded that the increased lymphocyte RNA content found in patients with rheumatoid arthritis is evidence of the participation of the lymphocyte in the immunological derangements of the disease, and that the RNA/DNA ratio of the lymphocyte may be a useful means of measuring immunological activity.

\section{REFERENCES}

Birbeck, M. S. C., and Hall, J. G. (1967). Nature (Lond.), 214, 183 (Transformation, in vivo, of basophilic lymph cells into plasma cells).

Buckton, K. E., Jacobs, P. A., Court Brown, W. M., and Doll, R. (1962). Lancet, 2, 676 (A study of the chromosome damage persisting after $x$-ray therapy for ankylosing spondylitis).

Coulson, A. S., and Chalmers, D. G. (1964). Ibid., 1, 468 (Separation of viable lymphocytes from human blood).

Doniach, D., and Roitt, I. M. (1962). Ann. Rev. Med., 13, 213 (Auto-antibodies in disease).

Everett, N. B., Caffrey, R. W., and Rieke, W. O. (1964). Ann. N.Y. Acad. Sci., 113, 887 (Recirculation of lymphocytes).

Fleck, A., and Munro, H. N. (1962). Biochim. biophys. Acta, 55, 571 (The precision of ultraviolet absorption measurements in the Schmidt-Thannhauser procedure for nucleic acid estimation).

Glen, A. C. A. (1967). Clin. Chem., 13, 299 (Measurement of DNA and RNA in human peripheral blood lymphocytes).

— Cooper, W. C., Jacob, S. T., Boak, J. L., Murray, J. E., and Munro, H. N. (1967). In preparation.

Glynn, L. E., and Holborow, E. J. (1965). "Autoimmunity and Disease". Blackwell Scientific Publications, Oxford.

Gowans, J. L. (1959). J. Physiol. (Lond.), 146, 54 (The recirculation of lymphocytes from blood to lymph in the rat).

Harris, J., and Vaughan, J. H. (1961). Arthr. and Rheum., 4, 47 (Transfusion studies in rheumatoid arthritis).

Hirschhorn, K., Bach, F., Kolodny, R. L., Firschein, I. L., and Hashem, N. (1963). Science, 142, 1185 (Immune response and mitosis of human peripheral blood lymphocytes in vitro).

Holborow, E. J. (1967). Lancet, 1, 1208 (An ABC of modern immunology).

Leslie, I. (1960). "The Nucleic Acids". Academic Press, New York.

Restifo, R. A., Lussier, A. J., Rawson, A. J., Rockey, J. H., and Hollander, J. L. (1965). Ann. intern. Med., 62, 285 (Experimental production of arthritis by the intra-articular injection of purified 7s gamma globulin).

Ropes, M. W. (1959). Ann. rheum. Dis., 18, 49 (Diagnostic criteria for rheumatoid arthritis. 1958 revision).

Sell, S., and Gell, P. G. H. (1965). J. exp. Med., 122, 423 (Stimulation of blast transformation with an antiallotype serum).

Wardle, E. N., and Attan, J. (1967). Brit. J. Haematol., 13, 194 (An electron microscope study of bone marrow in rheumatoid disease). 
Le teneur des lymphocytes en ADN et en ARN dans la polyarthrite rhumatoide

\section{RÉSUMÉ}

On détermina le taux moyen d'ADN et d'ARN dans les lymphocytes provenant du sang périphérique de 35 malades atteints de polyarthrite rhumatoïde; chez 24 d'entre eux la maladie était "definie" et chez 11 "probable", selon les critères diagnostiques de l'American Rheumatism Association. On fit la même chose chez 40 sujets sains. On mit en évidence une augmentation appréciable du taux lymphocytaire d'ARN chez les malades atteints de polyarthrite rhumatoïde "definie" par rapport aux témoins. On discute les raisons probables de cette différence à propos des réactions bien connues du lymphocyte à l'égard des stimulants immunologiques et des produits médicamenteux. On conclut que la teneur en ARN augmentée des lymphocytes, trouvée chez des malades atteints de polyarthrite rhumatoïde, constitue une preuve de la participation du lymphocyte dans le dérangement morbide et que la raison ARN/ADN du lymphocyte peut être utile pour mesurer l'activité immunologique.
Las cifras linfocitarias de ADN y de ARN en la poli $\frac{0}{\sigma}$ artritis reumatoide

\section{SUMARIO}

Se determinaron las cifras medias de ADN y de ARN en linfocitos de las sangre periférica de 35 enfermos con poliartritis reumatoide, que fué "definida" en 24 casos $\overline{\bar{X}}$ "probable" en 11 casos, según los criterios diagnósticos de la American Rheumatism Association. Se hizo lø mismo en 40 sujetos sanos. Se evidenció un aumentō. apreciable de las cifras linfocitarias de ARN en enfermos, con poliartritis reumatoide "definida" en comparación con los testigos. Se discuten las causas probables de esta diferencia en relación con las reacciones conocidas deth linfocito hacia estímulos inmunológicos y productos: medicamentosos. Se concluye que las cifras aumentadas de ARN en leucocitos, encontradas en enfermos con poliartritis reumatoide, ofrecen una prueba de la parti cipación del linfocito en el desarreglo morboso y que las razón ARN/ADN del linfocito puede utilizarse parß̧ medir la actividad inmunológica. 